\title{
Pallagi AnIKó*
}

\section{Büntethető gyermekkorúak}

\author{
gyermekkor - büntethetőség - belátási képesség - kodifikáció
}

A gyermek- és fiatalkorúak bủnözése manapság egyre növekvő aggodalmat okoz a társadalomban. Hazánkban is, de európai és nemzetközi szinten is állandó vizsgálat tárgyát képezi a fiatalok bủnelkövetés okainak feltárása, illetve a velük kapcsolatban alkalmazott jogi szabályozás irányainak és módszereinek kidolgozása.

A gyermek- és fiatalkorúak jogellenes cselekményeinek általában nagyobb társadalmi visszhangja van, a bűncselekményt elkövető fiatalok társadalmi megítélése ezért különösen rossz. Bár hazánkban a statisztikai adatok szerint a gyermekkorú lakónépesség csupán két ezreléke válik bünelkövetővé, és csak elvétve történnek kirívóan súlyos, élet elleni cselekmények, a média azonban az ilyen esetekre, azok hírértéke miatt nagyobb hangsúlyt helyez, és ezzel a közvéleményben negatív hangulatot kelt. Sajnos sokszor találkozhatunk olyan kijelentésekkel, amelyek szerint a gyermekek által elkövetett erőszakos büncselekmények száma jelentősen emelkedik, és a társadalom nagy része hajlamos az ilyen kijelentések igazságtartalmának vizsgálata nélkül arra az álláspontra helyezkedni, hogy helyes lenne a büntethetőségi korhatárt minél alacsonyabban meghatározni, és ezeket a gyerekeket akár életük végéig is „rács mögé dugni”. A szenzációt kereső média kiemelten fontos hírként azonnal közzéteszi a gyermekek által elkövetett büncselekményekről szóló értesüléseket, különösen, ha az valamilyen személy elleni erőszakos cselekményi körbe tartozik, nemegyszer olyan negatív kicsengéssel befolyásolva a hírolvasókat, hogy a büntetőjogi szabályozás hibája folytán ezek a cselekmények nem vonnak maguk után következményeket. Így teljes mértékben érthető, hogy a törvényeket és egyéb jogszabályi rendelkezéseket alapvetően csupán a médiából ismerő emberek véleményt, kritikát fogalmaznak meg a büntető jogszabályokkal kapcsolatban vagy egyéb büntetőjogi kérdésekben, és a gyermekkorú elkövetők büntethetőségének megteremtését követelik. ${ }^{1}$

* Dr. Pallagi Anikó egyetemi adjunktus, Nemzeti Közszolgálati Egyetem Rendészettudományi Kar Bünügyi Tudományok Intézete Büntetőjogi Tanszék, pallagi.aniko@uni-nke.hu.

1 Ezt tükrözi a 2011 áprilisában J. Cs. magánszemély kezdeményezésére elindult aláírásgyűjtés, hogy legyen-e népszavazás a büntethetőségi korhatár csökkentésének kérdésében. A népszavazásra feltenni kívánt kérdés („Egyetért-e Ön azzal, hogy büntetőeljárásokban a büntethetőség alsó korhatára 12 év legyen?”) azonban nem állta ki az Alkotmánybíróság „próbáját”, ugyanis hiába hitelesítette az aláírásgyűjtő ív mintapéldányát az OVB 34/2011. (IV. 12.) határozatával, az ez ellen benyújtott kifogások alapján az Alkotmánybíróság a 60/2011. (VII. 7.) AB-határozatával az OVB döntését megsemmisítette. Indokolása szerint a népszavazásra feltenni kívánt kérdés nem felel meg az egyértelmüség követelményének: a választópolgárok nem tudják megítélni, hogy milyen jogalkotást támogatnak, és eredményes népszavazás esetén a törvényhozó sem tudná meghatározni jogalkotási kötelezettsége tartalmát. 
Pedig a büntethetőség alsó korhatárának meghatározása kiemelten fontos büntetőpolitikai szakkérdés. Hazánkban a 2013 júliusában hatályba lépett új Büntető törvénykönyv megtartotta azt a korábbi szabályozást, amely továbbra is fő szabályként vélelmezi, hogy a tizennegyedik életévet be nem töltött gyermekek még nem rendelkeznek a büntetőjogi felelősségre vonáshoz szükséges beszámítási képességgel, így nem büntethetők. Öt kiemelten súlyos büncselekmény esetében azonban megdönthetővé vált e törvényi vélelem a tizenkettedik életévét betöltött fiatalok vonatkozásában.

Az új Btk., a 2012. évi C. törvény elfogadása körüli időben a média - a téma hírértékének kihasználásával - az új szabályozás elleni kampányba kezdett, és sorra jelentek meg cikkek, tudósítások és nyilatkozatok arról, hogy hazánkban 2013. július 1-jétöl már gyermekek is börtönbe zárhatók lesznek, illetve a büntetőeljárás során akár előzetes letartóztatásuk is elrendelhető. Teljesen egyetértek az e témában nyilatkozó szakértőkkel abban a kérdésben, hogy a veszélyeztetett gyermekeknek elsősorban ,jó minőségű” gyermekvédelmi szolgáltatásokat kellene szervezni, bűncselekmény elkövetése esetén pedig nevelésüket inkább valamilyen tevőleges megbánást tanúsító jóvátételi munkával kell megszervezni, azonban az információ bármelyik irányban történő torzítása káros következményekkel járhat mind hazánkban, mind pedig hazánk nemzetközi megítélése terén. A témában nyilatkozó egyes szakemberek szerint ugyanis egyrészt az új Btk.-nak a gyermekkorral kapcsolatos rendelkezései az ENSZ Gyermekjogi Egyezményének elveibe ütköznek, amely kimondja, hogy gyermekkorú és fiatalkorú bűnelkövetőket csak a legvégső esetben szabad elzárással sújtani, másrészt a kormányzati erőfeszítések inkább a büntetésre irányulnak, nem pedig a hatékony kezelésre és megelőzésre. ${ }^{2}$ Álláspontom sze-

2 Lásd többek között:

- az Origo hírportálon e témában 2012. május 15-én megjelent cikk, Ellenzi a büntethetőségi korhatár leszállítását az ombudsman címmel: http://www.origo.hu/itthon/20120515-ellenzi-a-buntethetosegi-korhatarleszallitasat-az-ombudsman.html;

- az UNICEF Magyar Bizottságának állásfoglalása a büntethetőségi korhatár leszállításáról, amely Gyurkó Szilvia az UNICEF gyermekjogi szakértőjének tolmácsolásában került a youtubra feltöltésre: http://www. youtube.com/watch?v=qPyvewUdNco;

- az MTI 2012. június 25-i közleménye szerint: „Civil szervezetek ellenzik, hogy bizonyos bủncselekmények esetén 12 évre csökkentsék a büntethetőségi korhatárt. A megoldás nem a büntetés, nem a tárgyalótermek és rendőri kezek, hanem a gyermekek nyelvén értő szakemberek, pártfogók, pszichológusok, szociális munkások és a szülők közös munkája." A dokumentum aláírói között van Gönczöl Katalin egyetemi tanár, kriminológus, Muhi Erika, a Nemzeti és Etnikai Kisebbségi Jogvédő Iroda igazgatója, valamint Márton Izabella, a Magyar Szegénységellenes Hálózat igazgatója, http://www.nepszava.hu/articles/article.php?id=563782;

- a hvg.hu hírportálon 2012. június 26-án ENSZ-egyezményt sértett Magyarország az UNICEF szerint címmel: http://hvg.hu/itthon/20120626_unicef_ensz_egyezmeny; majd pár órával ezt követően ugyanezen hírportálon jelent meg a kormány álláspontja, Alaptalannak nevezte az UNICEF tiltakozását a KIM címmel: http://hvg.hu/itthon/20120626_kritika_kim;

- 2012. augusztus 31-én az Élet és Irodalom 2012. 35. számában TótH Mihály: Egy büntetőjogász gondolatai a „vox populi” oldalvizén című dolgozata;

- az Origo internetes hírportálon 2012. november 28-án nyilatkozott Nyilas Anita, a D.A.S. JogSzervíz szakértője, Nincs szakmai konszenzus a büntethetőségi korhatár leszállításáról címmel: http://www.origo.hu/jog/ lakossagi/20121128-nincs-szakmai-konszenzus-a-buntethetosegi-korhatar-leszallitasarol.html; 
rint ezek az állítások nem minden esetben a valós helyzetet tükrözik, ezért tanulmányomban az új Büntető törvénykönyvnek a büntethetőségi korhatárral kapcsolatos rendelkezéseit, a szabályozás előzményeit, indokait és esetleges módosításának lehetőségeit kívánom körüljárni.

\section{A büntethetőségi korhatár változása a magyar büntetőjogban}

Jogtörténeti szempontból hazánkban csupán ötven éve van a büntethetőségi korhatár a tizennegyedik életévben meghatározva. A középkorban hagyományosan a tizenkettedik életév betöltése jelentette a törvényes kor elérését, ${ }^{3}$ amelynek betöltésétől a személy vétőképesnek volt tekintendő. ${ }^{4}$ Hazánk első büntető törvénykönyve, az 1878. évi V. törvénycikk (Csemegi-kódex) nem tartalmazott külön fejezetbe foglalt szabályozást a fiatalkorúakra, azonban a törvény általános részében megfogalmazta a büntethetőség alsó korhatárát, illetve a fiatalkorúakkal kapcsolatos speciális rendelkezéseket. ${ }^{5}$

A Csemegi-kódex az alsó korhatárt a tizenkettedik életévben határozta meg, azonban a tizenkettő és tizenhat év közötti gyermek sem volt büntethetö, ha a cselekménye bünösségének felismeréséhez szükséges belátással nem bírt. ${ }^{6}$ Így a kódex 84. §-a szerint: „Aki akkor, midőn a büntettet vagy vétséget elkövette, életkorának 12-ik évét már túlhaladta, de tizenhatodik évét még be nem töltötte, ha cselekménye bünösségének felismerésére szükséges belátással nem birt, azon cselekményekért büntetés alá nem vehető. Az ilyen kiskorú azonban javító-intézetbe való elhelyezésre ítéltethetik, de abban életkora huszadik évén túl nem tartathatik." ' Az a kiskorú azonban, aki cselekménye elkövetésének idején rendelkezett belátási képességgel, büntethető volt, bár jóval enyhébben, az úgynevezett redukált büntetési tábla szerint. ${ }^{8} \mathrm{~A}$ kódex rendelkezett arról is, hogy a szabadságvesztés teljes tartama alatt a többi fogvatartottaktól elkülönítve kellett elhelyezni e kiskorúakat.

A századforduló magyar büntetőjog-tudományában meghatározó pozitivista büntetőjogi irányzat és ennek bizonyos tételeit a klasszikus iskola tanaival ötvöző közvetítő irányzatok közül a Franz von Liszt-féle felfogás térhódítása következtében egyre inkább szükségessé vált a büntetőjogi rendszer részbeni átépítése. A fiatalkorúakra irányadó szabályok kidolgozásának kiindulópontja az a felismerés volt, hogy a fiatalok erkölcsi romlástól való megmentése alapvetően szociálpolitikai intézkedésektől

- a Jogi fórum weboldalon 2013. november 22-én megjelent Lévay Miklóssal készített interjú http://www. jogiforum.hu/interju/114.

3 Bizonyos esetekben azonban a büntethetőségnek az életkoron túl más, személyi jellegủ kapcsolatra való hivatkozás is követelménye volt. Lásd például MADAI Sándor: A csalás tényállásának hazai előképei az államalapítástól a felvilágosodás koráig. Jogtörténeti Szemle, 2009/4, 19.

4 MeZEY Barna: A kor kérdése a magyar büntetőjog történetében. Rendészeti Szemle, 2008/7-8, 22.

5 1878. évi V. tc. 83-86. §.

6 Konkrét bủncselekményt vizsgálva például a csalás kapcsán nem pusztán a megfelelő életkor betöltését kívánta meg a gyakorlat, hanem azt is, hogy az elkövető képes legyen fondorlatos módon mást tévedésbe ejteni vagy tartani. MADAl: $i$. m., 25.

7 1878. évi V. tc., 84. §.

8 Mezey: i. m., 27. 
várható. Ehhez azonban - a már bűncselekményt elkövetett fiatalok speciális prevenciója érdekében - büntetőjogi reformnak is társulnia kellett. ${ }^{9} \mathrm{E}$ reformelképzelések eredményeképpen az 1908. évi XXXVI. tc. (ún. I. büntetőnovella, a továbbiakban: I. Bn.) megteremtette a fiatalkorúak büntetőjogát. A szabályozást kiegészítette a fiatalkorúak bíróságáról szóló 1913. évi VII. tc., amely az I. Bn. eljárási alapjait teremtette meg. ${ }^{10}$

$\mathrm{Az}$ I. Bn. külön fejezetbe foglalta a fiatalkorúakra vonatkozó rendelkezéseket. A büntethetőség alsó korhatárát meghagyta a tizenkettedik életévben, azonban a belátási képesség fogalmának elemeit is meghatározta, azaz csak az a fiatalkorú volt büntetőjogi felelősségre vonható, akinek a büntett vagy vétség elkövetésekor a büntethetőséghez szükséges értelmi és erkölcsi fejlettsége megvolt. ${ }^{11} A$ fiatalkorúak büntetőjogi felelősségének átalakítása mellett az I. Bn. a klasszikus iskola proporcionális büntetési rendszere helyett a nevelésre helyezte a hangsúlyt. Ennek megfelelően kialakította a fiatalkorúak nevelésére és védelmére irányuló szankciórendszert, amely figyelemmel volt a fiatalkorú személyiségére, egyéniségére, értelmi és erkölcsi fejlettségének fokára. ${ }^{12}$

A Csemegi-kódex Általános Részét hatályon kívül helyező 1950. évi II. tv. (Btá.) a fiatalkorúakkal kapcsolatban már nem tartalmazott szabályozást. A törvény 9. §-a csupán azt határozta meg, hogy nem büntethető, aki a büntett elkövetésekor tizenkettedik életévét még nem töltötte be. A fiatalkorúakkal kapcsolatos anyagi és eljárásjogi normák külön jogszabályba kerültek, az 1951. évi 34. törvényerejü rendeletbe (Ftvr.), amely hatályon kívül helyezte az I. Bn. és az 1913. évi VII. tc. rendelkezéseit. E joganyag már nem tartalmazta a fiatalkorú büntethetőséghez szükséges értelmi és erkölcsi fejlettség követelményét, lehetővé tette azonban a büntetőeljárás mellőzését, megszüntetését, ha a fiatalkorú - értelmének fejlettsége folytán - nem ismerhette fel cselekménye társadalomra veszélyességét. A jogkövetkezmények szempontjából az Ftvr. értelmében a tizenkettő és tizennegyedik életév közötti fiatalkorúval szemben csak intézkedést lehetett alkalmazni, büntetés kiszabására csak a tizennégy év feletti fiatalkorú elkövetőknél volt lehetőség. ${ }^{13}$

A Csemegi-kódexet felváltó 1961. évi V. törvény, azaz a szocialista büntető törvénykönyv hatályon kívül helyezte az Ftvr.-t is, így megszűnt a fiatalkorúakra vonatkozó anyagi és eljárásjogi szabályoknak a külön, önálló jogszabályban való összefoglalása. E kódex a büntethetőséget kizáró okok között sorolta fel a gyermekkort, amelynek alsó korhatárát a tizennegyedik évre emelte fel. Indokolása szerint az ember a tizennegyedik életévének betöltésével válik beszámíthatóvá, azaz kerül a cselekedetének értékelésére és az annak megfelelő magatartás tanúsítására való képesség birtokába. A törvénykönyv a fiatalkorúak esetében is az általános bünte-

9 LÉVAY Miklós: Az I. büntető novella fiatalkorúakra vonatkozó rendelkezései. Jogtörténeti Szemle, 2008/4, 28-29.

10 LIGETI Katalin: A fiatalkorúak büntető igazságszolgáltatási törvényének koncepciója. Büntetőjogi Kodifikáció, 2006/2, 21.

11 1908. évi XXXVI. tc., 15-31. §.

12 LENKovics Judit: Adalékok az I. büntetőnovellához és a fiatalkorúak bíróságáról szóló törvényhez. Rendészeti Szemle, 2008/7-8, 44-45.

13 LIGETI: $i$. m., 22. 
tőjogi szabályokat kívánta maradéktalanul érvényesíteni, a fiatalkorúak társadalmi helyzetének, értelmi-pszichikai sajátosságainak figyelembevételével, így a fiatalkorúakra vonatkozó speciális büntetéskiszabási elveket és szabályokat a kódex Általános Részének külön fejezetében helyezte el. ${ }^{14}$

Az 1978. évi IV. törvény - hasonlóan az 1961. évi V. törvényhez - a gyermekkort mint büntethetőségi akadályt határozta meg, és határát generálisan a tizennegyedik életévben állapította meg. A fiatalkorúakra vonatkozó speciális rendelkezéseket a korábbi Btk. Általános Részének is egy különálló fejezete tartalmazta. A fiatalkorúakkal szembeni alkalmazott büntetőjogi szankció általános céljaként a fiatalkorú helyes irányú fejlődését és a társadalom hasznos tagjává válásának elősegítését jelölte meg. A szankciók közül az intézkedések alkalmazása volt az elsődleges, büntetést akkor lehetett kiszabni, ha az intézkedés alkalmazása nem volt célravezető. ${ }^{15}$

\section{Kodifikációs törekvések}

Hazánkban - a nemzetközi tendenciáknak megfelelően - az 1990-es évektől kezdődően több, a fiatalkorúakra vonatkozó büntetőjogi szabályozás reformját sürgető tanulmány jelent meg. ${ }^{16}$ Ugyanakkor megfigyelhető, hogy az ezredforduló időszakában megugró bűnözési statisztika hatására megindult a gondolkodás a büntethetőség alsó korhatárának a tizenkettedik életévre történő leszállításáról is.

2001-ben a Btk. felülvizsgálatára és az új kódex előkészítésére bizottság alakult. E bizottság megbízásából Lévay Miklós és Váradi Erika tanulmányt készítettek a fiatalkorúak büntetőjogának reformjáról. A tanulmányban a szerzők sem a büntethetőségi korhatár leszállítását nem tartották indokoltnak, sem pedig a fiatalkorúság felső határát, vagy esetleg a fiatal felnőtt kategória bevezetését. Állást foglaltak azonban a fiatalkorúakra vonatkozó olyan különálló törvény megalkotása mellett, amely a fiatalkorúakra vonatkozó anyagi jogi, eljárásjogi és végrehajtási szabályokat tartalmazná. ${ }^{17}$

2006-ban Ligeti Katalin dolgozta ki a fiatalkorúak büntető igazságszolgáltatási törvényének koncepcióját, amely a büntethetőség alsó korhatárára vonatkozóan két lehetőséget fogalmazott meg. A szerző által jobban preferált megoldás a hatályos büntetőjogi szabályozás változatlanul hagyása, azaz a büntetőjogi felelősségre vonás korhatárának a tizennegyedik életévben való meghatározása. Azonban alternatív megoldásként felállított egy olyan rendszert is, amely a korhatárt a tizenkettedik

4 LIGETI: i. M., 23.

15 1978. évi IV. törvény 108. §.

16 Többek között említhető LÉVAY Miklós: A fiatalkorúak igazságszolgáltatási rendszerére vonatkozó ENSZ minimum szabályok: a „Pekingi Szabályok”. Jogtudományi Közlöny, 1989/12. NAGY Ferenc: A fiatalkorúak büntetőjogi reformjának szükségességéről egy nemzetközi tudományos konferencia tapasztalatai alapján. Magyar Jog 1994/5. BogÁR Péter-MARGITÁN Éva-VASKUTı András: Kiskorúak a büntető igazságszolgáltatásban. Budapest, KJK Kerszöv, 2005. FüLÖP Ágnes-NAGY Emese: Új törekvések a fiatalkorúak büntetőjogában. Kriminológiai Tanulmányok, 42. kötet, OKRI, 2005.

17 CSEMÁNÉ VÁRADI Erika-LÉVAY Miklós: A fiatalkorúak büntetőjogának kodifikációs kérdéseiröl - történeti és jogösszehasonlító szempontból. Büntetőjogi Kodifikáció, 2002/1, 12-27. 
életévre szállítaná le, ám a tizenkettedik életévet betöltött, de tizennégy év alatti fiatalkorúak csak az élet, testi épség és egészség elleni bủncselekmények elkövetése esetén lennének büntethetők, és büntetésként velük szemben csak javítóintézeti nevelés lenne alkalmazható. Tervezete szerint az elkövetéskor a tizennyolcadik életévet betöltött, de a huszonegyedik életévet be nem töltött elkövetők az ún. fiatal felnőtt kategóriába tartoznának, akikkel szemben szintén e törvény szabályait kellene alkalmazni. A javaslat valamennyi fiatalkorúval kapcsolatban generálisan előírta a belátási képesség vizsgálatát, amelynek hiányát büntethetőséget kizáró okként határozta meg. ${ }^{18}$

\section{Az új Btk. szabályai a büntethetőség korhatáráról}

2012. június 25. napján az Országgyűlés elfogadta a hazánk új Büntető törvénykönyvéről szóló 2012. évi C. törvényt, amely megtartotta a jelenleg hatályban lévő Btk. szerinti tizennegyedik életévben meghatározott büntethetőségi korhatár fő szabályát, azonban öt kiemelten súlyos bűncselekmény esetén leszállította a büntethetőségi korhatárt tizenkét évre. A büntethetőség azonban ezekben az esetekben a belátási képesség vizsgálatához kötött. ${ }^{19}$

Az új Btk. parlamenti tárgyalása során is viták kereszttüzébe került a büntethetőségi korhatár leszállításának kérdése. ${ }^{20}$ Megjegyzendő, hogy az eredeti kormány-előterjesztés a büntethetőség alsó korhatárát nem kívánta megváltoztatni, és a kormány által az Országgyülés elé terjesztett T/6958. törvényjavaslat is csak a szándékos emberölés alap- és minősített esetei, az erős felindulásban elkövetett emberölés, illetve az életveszélyt és halált okozó testi sértés vonatkozásában szállította le az életkori határt, amely módosító indítvány nyomán bővült ki a rablás és a kifosztás tényállásaival.

A 2012. évi C. törvény indokolása szerint az életkornak meghatározó jelentősége van a büntetőjogi felelősségre vonás szempontjából. A tizennégy éves korhatár megállapításának az indoka az, hogy a gyermekek nagyobb része ebben a korban fejezi be általános iskolai tanulmányait, és ér el olyan testi és szellemi fejlettségi szintet, amelyre tekintettel büntetőjogi felelősségre vonható. Napjainkban azonban

18 LIGETI: $i$. m., 34

19 A Büntető törvénykönyvről szóló 2012. évi C. törvény 16. §: „Nem büntethető, aki a büntetendő cselekmény elkövetésekor a tizennegyedik életévét nem töltötte be, kivéve az emberölés [160. § (1)-(2) bekezdés], az erős felindulásban elkövetett emberölés (161. §), a testi sértés [164. § (8) bekezdés], a rablás [365. § (1)-(4) bekezdés] és a kifosztás [366. § (2)-(3) bekezdés] elkövetőjét, ha a bűncselekmény elkövetésekor a tizenkettedik életévét betöltötte, és az elkövetéskor rendelkezett a büncselekmény következményeinek felismeréséhez szükséges belátással."

20 Ebben a kérdésben több módosító javaslat is érkezett, így az LMP képviselői által benyújtott T/6958/4. számú módosító javaslat, amely a büntethetőségi korhatár leszállítását teljes mértékben ellenezte (Szabó Tímea és dr. Dorosz Dávid - LMP); a Jobbik képviselői által benyújtott T/6958/152. számú módosító a büntethetőség korhatárának generális leszállitását javasolta (dr. Apáti István, Szilágyi György, dr. Staudt Gábor és dr. Gyüre Csaba - Jobbik); a Fidesz képviselői által benyújtott T/6958/169. számú módosító javaslat pedig kibővítette a rablás és a kifosztás eseteivel a leszálított korhatárba tartozó bűncselekmények körét (Balázs József, Csöbör Katalin, dr. Daher Pierre és Demeter Zoltán - Fidesz - Magyar Polgári Szövetség). 
a gyermekek biológiai fejlődése felgyorsult, a gyermekek korábban „érnek”, az információs forradalom következtében a kiskorúakat már tizennegyedik életévüket megelőző életszakaszukban elérik a társadalom olyan különféle hatásai, amelyektől a korábbi időkben még védve voltak. ${ }^{21}$

Az új Btk. a felsorolt öt bủncselekmény esetében akkor teszi lehetővé tizenkettedik életévét betöltött elkövető büntetőjogi felelősségre vonását, ha az elkövetéskor rendelkezett a cselekménye következményeinek felismeréséhez szükséges belátással. Sajnos a törvény adós maradt a belátási képesség fogalmának, elemeinek és vizsgálati szempontjainak meghatározásával, így e kérdések megoldása a jogalkalmazói gyakorlatra hárul. Bár a belátási képesség fogalmat a jogrendszerünk inkább polgári jogi kategóriaként ismeri, de a büntetőjogi dogmatikától sem idegen, tekintettel arra, hogy a már említett I. Bn. rendelkezései szerint a fiatalkorúak büntetőjogi felelősségének megállapítása a meghatározott életkoron és a beszámítási képesség meglétén túl a belátási képességen alapult, amely az elkövető értelmi és erkölcsi fejlettségét jellemezte. Ennek vizsgálata igen komplex, hiszen azt kell eldönteni, hogy az ép elmeműködésű fiatalkorú elkövető erkölcsileg és értelmileg kellően fejlett-e.

Az egységes ügyészségi joggyakorlat érdekében - a legföbb ügyész helyettese adott ki körlevelet, amely a belátási képesség vizsgálata kapcsán fogalmaz meg fontos szempontokat. ${ }^{22} \mathrm{~A}$ körlevél rögzíti, hogy a belátási képesség vizsgálatának első lépcsője az elmeállapotra vonatkozóan elvégzett igazságügyi elmeorvos szakértői vizsgálat, amely ha megállapítja, hogy a tizennegyedik életévét be nem töltött fiatalkorú terhelt beszámítási képessége kizárt, a belátási képesség tekintetében a további vizsgálat szükségtelen.

Lényeges, hogy a belátási képesség megállapíthatóságához az igazságügyi elmeorvos szakértői vélemény mellett pszichológus szakértői véleményt ugyancsak be kell szerezni. Emellett gyermekpszichiáter szakkonzulens bevonása is indokolt lehet. A szakértői vizsgálat elvégzéséhez soron kívül be kell szerezni és a szakértő rendelkezésére kell bocsátani a tizenkettedik életévét betöltött, de a tizennegyedik életévét be nem töltött fiatalkorú terheltröl készült környezettanulmányt, pedagógiai és iskolai jellemzést, az esetleges gyermekvédelmi intézkedésekre, illetve a korábbi megbetegedésekre, a fizikai és pszichés állapotra vonatkozó orvosi iratokat és dokumentumokat.

A körlevél kiemeli, hogy az elkövetőnek a cselekmény következményei felismeréséhez szükséges belátás meglétéről a szakértői vélemény és a rendelkezésre álló valamennyi adat együttes körültekintő értékelésével - szükség esetén a tizenkettedik életévét betöltött, de a tizennegyedik életévét be nem töltött fiatalkorú terhelt ügyészi kihallgatását követően - lehet állást foglalni.

Az új Btk.-ban - a büntethetőségi korhatár szektorális leszállítása miatt - a fiatalkorú fogalma is megváltozott: a fiatalkorúság a tizenkettedik életév betöltésétől a tizennyolcadik életév betöltéséig tart. A fiatalkorúakra vonatkozó büntetőjogi sza-

21 2012. évi C. törvény indokolása.

22 5/2013. (VII. 31.) LÜh. körlevél a tizenkettedik életévét betöltött, de a tizennegyedik életévét be nem töltött fiatalkorú terheltek büntetőjogi belátási képességének a megítéléséröl. Ügyészségi Közlöny, 2013/7, 183. 
bályok - követve a már több mint ötven éve kialakított szerkezetet - nem különülnek el az általános rendelkezésektől, hanem azokat ezúttal is az egységes büntető törvénykönyv általános részének külön fejezete tartalmazza. A kódex rögzíti, hogy a fiatalkorú elkövetők vonatkozásában a büntetőjog elsődleges feladata a nevelés, amely különösen a tizenkettő-tizennégy év közötti korosztály tekintetében igaz. Erre figyelemmel a törvény kimondja, hogy a tizennegyedik életévüket be nem töltött személyekkel szemben csak intézkedés alkalmazható, továbbá a szabadságelvonással nem járó intézkedésnek meg kell előznie a szabadságelvonással járó intézkedés (javítóintézeti nevelés) alkalmazását. ${ }^{23}$ Így végső soron megállapítható, hogy ugyan az új Btk. megteremtette a tizenkettedik életévét betöltött, de tizennegyedik életévét be nem töltött fiatalkorúak büntetőjogi felelősségre vonásának lehetőségét, azonban ezek a fiatalkorúak mégsem büntethetők, legsúlyosabb jogkövetkezmény esetükben az egytől négy évig terjedő tartamú javítóintézeti nevelés intézkedése lehet.

\section{Statisztikai adatok}

A hazai bünügyi és ügyészségi statisztikák vizsgálata során óhatatlanul felvetődik a kérdés, miért vált szükségessé a büntethetőség alsó korhatárának leszállítása?

Az új Btk. indokolása szerint a tizenkettő-tizennégy év közötti gyerekek körében egyre nagyobb mértékben elterjedt az erőszakos érdekérvényesítés, ezért szükséges a büntethetőségi korhatár módosítása, a kirívóan agresszív, élet ellen irányuló bủncselekményt megvalósító gyermekkorúak büntetőjogi felelősségre vonása és egyes súlyos büncselekményeknél a büntethetőség korhatárának leszállítása tizenkét évre. Az ilyen bűncselekményt megvalósító gyermekkorú magatartásából ugyanis arra lehet következtetni, hogy megfelelő segítség hiányában nem lesz képes a későbbiekben a társadalomba való beilleszkedésre és a törvénytisztelő életmódra, ezért a speciális prevencióhoz mindenképpen szükséges a büntetőjog eszközeinek igénybevétele. ${ }^{24}$

A Legföbb Ügyészség által készített statisztikák azonban a törvény indokolását nem támasztják alá. Magyarországon az utóbbi tíz évben a tizennégy éven aluli elkövetők száma évente 2573 és 3963 között alakult, átlagosan tehát évente 3300 bűncselekményt követtek el gyermekkorúak. Ez a szám az utóbbi négy évben jelentősen visszaesett. Míg 2002 és 2008 között ez a szám átlagosan 3600 körüli értéket mutatott, 2009-ben csupán 2573, 2010-ben 2607, 2011-ben 2714, 2012-ben pedig 2604 gyermekkorú elkövetőt regisztrált a statisztika. ${ }^{25} \mathrm{~A}$ gyermekkorúak, azaz a tizennégy év alattiak által elkövetett büncselekmények legnagyobb része kisebb vagyon elleni vétség, a szándékos emberölések száma évente átlagosan 1, míg a testi sértések száma is csupán átlagosan évente 190-re tehető, bár tény, hogy ez utóbbi körben a statisztikák emelkedő tendenciát mutatnak.

23 A Büntető törvénykönyvröl szóló 2012. évi C. törvény 105-106. §.

24 2012. évi C. törvény indokolása.

25 Készült a Legfőbb Ügyészség által kiadott tájékoztató a gyermekkorúak és fiatalkorúak bűnözésével összefüggő egyes kérdésekröl 2012. évre, http://www.mklu.hu/cgi-bin/index.pl?lang=hu/. 
Érdekes vélekedést fogalmaz meg ezzel kapcsolatban Sipos László, aki szerint a probléma a pönalizáció-depönalizáció viszonyában keresendő. Álláspontja szerint a statisztikai adatok ugyan azt mutatják, hogy a gyermekbűnözés csökken, azonban valójában ez a változás szinte teljesen elhanyagolható, csupán az elkövetési értékhatárok felemelése miatt érezhető a javulás az adatokban. ${ }^{26}$ Ezzel a megállapítással föleg azért nem tudok egyetérteni, hiszen a vagyon elleni bủncselekmények esetében - amelyek a gyermekkorú bủnelkövetés legnagyobb részét teszik ki - a büncselekményi értékhatár ötezerröl tízezerre történő emelésére 1999-ben került sor, ezzel szemben a bűnügyi statisztika ebben az időszakban szinte stagnálást mutatott, és 2007-ben, amikor a bűncselekményi értékhatárt tízezerről húszezer forintra emelte a jogalkotó, a statisztika szintén nem változott ugrásszerűen. A jelentős javulás 2009-töl tapasztalható.

Egyes vélemények szerint több figyelmet kellene fordítani a demográfiai adatok vizsgálatára, hiszen hazánkban a születések száma a 1990-es évek óta jelentősen csökken, így - bár a statisztikai adatokból ugyan kedvező tendenciákat olvashatnánk ki a gyermekkorúak bűnelkövetésének csökkenésére vonatkozóan - azonban a bủncselekményszám csökkenése talán inkább ennek a hatását hordozza magán. ${ }^{27}$ Ezzel szemben azonban a legújabb statisztikai adatok egyértelműen alátámasztják, hogy a 2009-es bűncselekményszám-csökkenés a gyermekkorúak vonatkozásában a teljes gyermekkorú lakónépesség szempontjából is csökkenést eredményezett. Míg ezt megelőzően a gyermekkorú lakónépesség 2,4-2,7 ezreléke követett el bűncselekményt, 2009-től kezdve ez az arány 2,0-1,9 ezrelékre változott.

$A z$ is igaz, hogy az ügyészségi statisztikák csupán a felderített bűncselekmények adataival számolnak, és a gyermekkorú elkövetők esetében nagymértékű latenciával kell számolni, tekintettel arra, hogy ilyen esetekben a sértettek ritkán tesznek feljelentést, illetve az oktatási intézmények is inkább pedagógiai problémaként tekintenek az ilyen esetekre. Mindezzel együtt azt a vélekedést, amely szerint a gyermekkorú búnelkövetés ténylegesen az akár évi több tízezres számot is elérheti, túlzásnak tartom. ${ }^{28}$

\section{Nemzetközi elöírások}

Az 1980-as évektől kezdődően a gyermekek védelmére és a fiatalkorúakra vonatkozó igazságszolgáltatási rendszerhez kapcsolódó számos nemzetközi egyezmény és szerződés született. Ebben a körben feltétlen említést érdemel az ENSZ Közgyülése által 1989. november 20-án elfogadott, a Gyermek Jogairól Szóló Egyezmény, amelyet hazánk az 1991. évi LXIV. törvénnyel hirdetett ki.

Az egyezmény a tizennyolcadik életévhez köti a gyermekkorúság határát, természetesen ez nem jelenti az egyes nemzeti szabályozásokra vonatkozó kötelező elő-

26 Sipos László: Adatok és gondolatok a magyarországi gyermekbünözésről. Ügyészek Lapja 2007/1, 7.

27 Ezzel kapcsolatban lásd KoRInek László: „Csecsszopók, akikben megnő az értelem”. A gyermekek büntethetőségéröl. Fundamentum 2008/2, 73, és SıPos: i. m., 7-8.

28 SiPOS: i. m., 6. 
írást például a büntetőjogi felelősség vagy a vétőképesség tekintetében. Az egyezmény értelmében azonban a gyermekkorúság önmagában olyan többletjogosítványokat teremt meg, amelyek kötelezőek az egyes eljárásokban. Ilyen kötelezettség, hogy a gyermeket a családjából csak végső esetben szabad kiemelni.

Meghatározónak tekinthetők az ENSZ ebben a témában létrehozott további jogi dokumentumai, így a fiatalkorúak igazságszolgáltatási rendszerére vonatkozó minimumszabályai („Pekingi Szabályok” 1985), a szabadságuktól megfosztott fiatalkorúak védelmére vonatkozó szabályai („Havannai Szabályok” 1990), a fiatalkori bűnözés megelőzésére vonatkozó iránymutatása („Rijádi Iránymutatás” 1990) és a minimum intervenció elvének kimondása („Tokiói Iránymutatás” 1990).

„A Pekingi Szabályok mintegy összegzése az ENSZ fiatalkori bünözéssel kapcsolatos bünmegelőzési törekvéseinek és kifejeződik benne a nyolcvanas évek bünmegelőzési, kriminálpolitikai koncepciója. Ez utóbbi értelmében a jogrendszerek és a büntető igazságszolgáltatás feladata az, hogy szolgálják az üdvös és méltányos fejlődés előmozdítását, kellő figyelemmel az emberi jogokra és a társadalmi igazság szempontjaira." ${ }^{29}$ A Pekingi Szabályok a fiatalkorúakra vonatkozó igazságszolgáltatás alapjainak körében kimondja, hogy a büntetés kiszabásakor az ügy súlyossága mellett, az elkövető személy élethelyzetét, szociális hátterét is figyelembe kell venni, s ennek ismeretében arányosan kell eljárni. Mindezek mellett fontos a fiatalkorúakat megillető jogok garantálása az eljárás valamennyi szakaszában. A Pekingi Szabályok előírása, hogy a fiatalkorú bünözők ügyében a lehető leghozzáértőbb testületnek kell eljárnia, és a fiatalkorú személyes szabadságának korlátozására csak gondos mérlegelés után kerülhet sor, és a szabadság korlátozását ebben az esetben is a lehetséges minimumra kell csökkenteni. Az intézmények általi ellátásnak a fiatalok társadalomba történő újra beilleszkedését kell elősegítenie, a felnőtt fogvatartottak káros hatásaitól mentesen.

Az 1990. december 14-én elfogadott 45/113-as számú ENSZ közgyűlési határozat a szabadságuktól megfosztott fiatalkorúak védelmének szabályairól („Havannai szabályok") 1. cikke kimondja, hogy fiatalkorúak esetében a szabadságvesztés csak végső eszközként, a legrövidebb szükséges időtartamra, és csak kivételes esetekben alkalmazható. Előírja továbbá - összhangban a Pekingi Szabályokkal -, hogy az ilyen szankció kiszabásáról minden esetben bíróságnak kell döntenie, mégpedig oly módon, hogy lehetőség legyen az eredeti bírósági döntésben foglaltnál korábbi szabadlábra helyezésre is.

A szintén 1990-ben elfogadott 45/112-es számú ENSZ közgyűlési határozat a fiatalkorú bűnözés megelőzésével kapcsolatban tartalmaz szabályokat („Rijádi Iránymutatások"). 5. cikkében kimondja, hogy a hangsúly az olyan preventív politikák létrehozásán van, melyek megkönnyítik a sikeres szocializációt és integrációt a fiatalok számára, illetve rámutat, hogy a fiatalkori bűnözés kezelése során a hangsúlyt a megfelelő szociális környezet biztosításával és az oktatáson keresztül a megelözésre kell helyezni. Arra hívja fel a figyelmet, hogy kifejezetten káros a fiatalkorút a társadalomban megbélyegző szankcióval stigmatizálni. 
A szabadságelvonással nem járó intézkedésekről szóló Tokiói Szabályok rendezik azokat a legalapvetőbb garanciákat, amelyek a szabadságvesztéssel nem járó szankciókkal sújtott személyek védelmét szolgálják. Kimondja, hogy a rendelkezéseket a minimális beavatkozás elvének alapulvételével kell alkalmazni, úgy, hogy a szabadságelvonással nem járó intézkedések alkalmazásának az általános dekriminalizálás és a pönalizálás visszaszorítása felé kell elmozdulást jelentenie.

Kiemelendők továbbá az Európa Tanács Miniszteri Bizottságának a gyermekek jogait illetően a tagállamok felé tett ajánlásai, legfőképpen a fiatalkorú bűnelkövetőkre vonatkozó igazságszolgáltatás szerepéről szóló R(2003)20. sz. ajánlás, amelynek értelmében a fiatalkorú elkövetőkkel szemben a büntető igazságszolgáltatás alapcélja a fiatalkorú nevelése a represszív és retributív célkitűzésekkel szemben, illetve hangsúlyt érdemel az Európa Tanács Miniszteri Bizottságának a gyermekbarát igazságszolgáltatásról szóló 2010. november 17-i iránymutatása is.

E dokumentumok nem fogalmaznak meg kötelező előírást a büntethetőség alsó korhatárának megállapításával kapcsolatban, azonban valamennyi említett dokumentum a fiatalkorúak büntetőjogának elkülönítését szorgalmazza. A hangsúly a felnőttkorú elkövetőkhöz képest a „más elbánásra” lehetőséget biztosító büntető igazságszolgáltatás kialakításán van, illetve ezt tartja a fiatalkorúak büntető igazságszolgáltatási rendszere elvárt fejlesztési irányának. ${ }^{30}$

\section{Kitekintés néhány európai ország szabályozására}

A büntethetőségi korhatár meghatározása Európában, illetve az Európai Unió tagállamaiban sem egységes, bár kimondhatjuk, hogy a büntethetőség alsó korhatára a legtöbb európai országban a tizennegyedik életév. Közismert tény azonban, hogy vannak olyan európai államok, amelyekben a büntetőjogi felelősségre vonás alsó határát a hazai szabályozáshoz képest alacsonyabban határozták meg, így Angliában és Svájcban a tizedik, ${ }^{31}$ Hollandiában és Görögországban a tizenkettedik, illetve Franciaországban a tizenharmadik életévben. Ezen államok jelentős részében azonban nemcsak az életkor, hanem más feltétel - így értelmi, erkölcsi, avagy akarati feltétel, ítélőképesség vagy belátási képesség megléte - is szükséges a büntetőjogi felelősség megállapításához. Tény az is, hogy vannak olyan országok, ahol a korhatár magasabb: például Spanyolországban, Portugáliában és Belgiumban a tizenhatodik életévben van megállapítva. Leszögezhetjük azonban, hogy egy adott országban a fiatalkorúak igazságszolgáltatási rendszerének jellege, minősége önmagában a büntethetőség alsó korhatára alapján nem ítélhető meg.

Az elmúlt évtizedben több európai országban sor került a fiatalkorúakkal kapcsolatos büntetőjogi eszközök reformjára. Néhány olyan országban, ahol a büntetőjo-

30 LIGETI: $i$. m., 24.

31 Svájcban a büntethetőség alsó korhatára 2006. december 31-ig a hetedik életévben volt meghatározva, majd a 2007. január 1-jén hatályba lépő Jugendstrafgesetzbuch (JStGB) e korhatárt a tizedik életévben határozta meg. Ebben a témában lásd bővebben: NAGY Ferenc: A fiatalkorúak új Svájci Büntető Törvényéről. Büntetőjogi Kodifikáció, 2007/2, 8-18. 
gi felelősségre vonás korhatára ugyan a tizennegyedik életév, már a tizenkettedik életévtől kezdődően igazságszolgáltatáson kívüli intézkedéseket teremtettek meg a súlyos büncselekményt elkövető gyermekekkel szemben. Így Olaszországban, Svédországban, illetve Hollandiában is gyermekvédelmi intézkedések tehetők ilyen esetben.

A problémát tulajdonképpen nem is a büntethetőség alsó korhatárának törvényben való megállapítása okozza, hiszen ez büntetőpolitikai szakkérdés. A legfontosabb feladatnak a fentiekben említett nemzetközi egyezményekben és ajánlásokban megfogalmazott elvárások tekinthetők, amelyek a fiatalkorúak büntetőeljárásának elkülönítését, a fiatalkorúakra vonatkozó speciális anyagi jogi, eljárási szabályok létrehozását és alkalmazását sürgetik. Ezek közül általánosan elismertnek tekinthető a fiatalkorúakkal kapcsolatban alkalmazandó szabadságelvonó szankciók ultima ratio jellege, és irányadónak tekinthető a szankciórendszer kialakításának alapjaként a „büntetés helyett nevelés” elve. ${ }^{32}$

\section{Jogtudományi vélemények}

A büntethetőség alsó korhatárának meghatározásában, illetve a fiatalkorú bűnelkövetés hatékony kezelésében régóta nincs megegyezés a büntetőjogászok és a kriminológusok között. A gyermekekkel foglalkozó szakemberek szerint egyértelmüen nem határozható meg egy konkrét életkor, amikor kijelenthetjük, hogy a gyermek rendelkezik a szükséges belátási képességgel. A gyermekek felgyorsult testi és lelki fejlődésével sok esetben nem jár együtt az értelmi, erkölcsi fejlettség, azonban a legsúlyosabb, elemi büntetendő cselekményeket elkövető tizennégy éven aluliak is tisztában lehetnek magatartásuk kiemelten veszélyes következményeivel, cselekményük tárgyi súlya pedig velük szemben is büntetőjogi reagálást igényel. ${ }^{33}$

Lévay Miklós és Váradi Erika fentiekben már hivatkozott tanulmányukban arra hívták fel a figyelmet, hogy a büntetőjog „végső eszköz” jellegére figyelemmel a tizennégy éven aluli gyermekek büntetendő cselekményeinek visszaszorítása, és az érintettek speciális prevenciója érdekében a büntetőjogi felelősség alsó korhatárának leszállítása helyett a gyermekvédelmi intézményrendszer - így a gyermekek védelméről szóló 1997. évi XXXI. törvény - továbbfejlesztése szükséges. ${ }^{34}$

Hasonlóképpen vélekedik erről a kérdésről Korinek László is, aki dolgozatában rámutat, hogy az ultima ratio követelménye alapján a büntetőjogi beavatkozás csak az olyan helyzetek kezelésére alkalmazható, amely esetekben minden más lehetőség lehetetlennek vagy kilátástalannak mutatkozik. Felhívja a figyelmet arra a tényre is, hogy a gyermekeket igen gyakran környezetük, családjuk taszítja a kriminalitás világába. Azonban a korhatárnak ilyen alapon történő leszállítása, és így a gyermeknek a rossz helyzetből való kiemelése és átadása a büntető igazságszolgáltatás

32 CSEMÁnÉ-LÉvay: i. m., 22.

33 Blaskó Béla-LaJTÁR István-Elek Balázs: A büntethetőséget kizáró vagy korlátozó okok. In Polt Péter (főszerk.): Új Btk. kommentár 1. kötet. Budapest, Nemzeti Közszolgálati és Tankönyv Kiadó, 2013, 125.

34 CSEMÁnÉ-LÉVAY: i. m., 25. 
intézményeinek többet árt neki, mint használ. Álláspontja szerint a korhatár leszállítása alapvetően szimbolikus értékü, és éppen ettől kellene megóvni a gyermekeket, hiszen a közvélemény nemigen tesz különbséget a büntetőjogi intézkedések és büntetések között, így a „címkéző-stigmatizáló” hatás tehát elkerülhetetlen. ${ }^{35}$ Nézete szerint „nem csupán azon kellene tehát gondolkodni, hogy a zsengébb korú gyermekeket bevonjuk-e a közhatalom repressziójának hatókörébe, hanem azon is, hogy esetleg a mai rendszerből még jobban kivonjuk a nagykorúságukat még el nem érő fiatalokat" ${ }^{36}$

Gellér Balázs József sem ért egyet a büntethetőség korhatárának leszállításával, véleménye szerint a gyermek- és fiatalkor határa nem csökken, hanem ellenkezőleg, inkább kitolódik, tekintettel az egyre több és komplexebb ismeretanyag elsajátításának szükségességére. ${ }^{37}$

Ezzel a felfogással összhangban Köhalmi László rámutat arra, hogy a jogalkotó nem vette figyelembe a posztadoleszcencia jelenségét, amely nemhogy a büntethetőségi korhatár leszállítását, hanem éppen ellenkezőleg, annak felemelését kívánná meg. ${ }^{38}$ Álláspontja szerint az új Btk.-nak a büntethetőségi korhatár leszállításával kapcsolatos normaszövege és annak indokolása is önellentmondásos és nem megalapozott. Nézete szerint a büntethetőségi korhatárnak a leszállítása tipikusan az a jogalkotási hiba, amikor a büntetőjog eszközeivel kívánnak társadalmi problémákat megoldani. „Egyes valóban kirívó, brutális büncselekmények miatt téves reakció a jogalkotói oldalon, ha egy egész korosztályt »büntet". Már évtizedekkel ezelőtt lefolytatott kutatások igazolták, hogy a represszió fokozása semmiféle eredményt nem hoz a gyermek- és fiatalkorúak esetében, sőt inkább ront a kriminalitási mutatókon." 39

Gyurkó Szilvia is elveti a büntethetőségi korhatár leszállítását, álláspontja szerint azonban nem az a fő kérdés, hogy milyen életkorban van meghatározva a büntethetőség alsó határa. „Vitathatatlan, hogy a gyermekkor kérdése egyedülálló módon képes relativizálni egyes jogdogmatikai fogalmakat (felelősség, beszámítási képesség, prevenció, szankció stb.), illetve magának a büntető anyagi és eljárási jognak a határait is. Fiatalkorúak esetén a jogalkalmazók eddig is jellemző módon lemondtak a büntetőigényröl, a büntethetőségi korhatár leszállításával pedig várhatóan még több alternatív elemmel bővülne a szankciórendszer." "40 Hangsúlyozza, hogy a gyermek- és fiatalkorúak bünözésének megelőzése területén a legfontosabb a veszélyeztetettség és a devianciák kialakulásának megelőzése. A hangsúlyt azonban nem elsősorban a bünüldözésre, még csak nem is a bünmegelőzésre, hanem az elsőd-

35 KoRINEK László: „Csecsszopók, akikben megnő az értelem”. A gyermekek büntethetőségéről. Fundamentum 2008/2, 69-78.

36 KORINEK: $i$. m., 76.

37 Gellér Balázs József: A Magyar Büntetöjog Tankönyve I. Általános Tanok. Budapest, Magyar Közlöny Lapés Könyvkiadó, 2008, 180.

38 KöHALMI László: A büntethetőségi korhatár kérdése. Jogelméleti Szemle 2013/1, 12.

39 Köhalmi: $i$. m., 13.

40 GYuRKó Szilvia: A büntethetőség alsó korhatára, valamint a gyermek- és fiatalkorú elkövetőkkel szemben alkalmazott jogkövetkezmények körüli dilemmák. In Kriminológiai Tanulmányok 45. kötet. Budapest, OKRI, 2008, 74. 
leges megelőzésre, így a gyermekvédelmi szektor személyi, tárgyi erőforrásainak megerősítésére kellene helyezni. ${ }^{41}$

Ezzel ellentétes álláspontot képvisel Benczúr Csaba, aki szerint vannak olyan bűncselekmények (pl. lopás), amelyek az általános erkölcs szabályainak talaján állnak, és ezek vonatkozásában már kilencéves kortól megállapítható a belátási képesség. „Egy tizenkét éves gyerek ma már akciófilmet, horrort néz, és kineveti társát, akit a magyar népmesék érdekelnek."42

Vaskuti András fővárosi tanácselnök bíró a Magyar Kriminológiai Társaság által „Életkor és belátási képesség” címmel rendezett tudományos ülésen tartott előadásában a bírói jogalkalmazás oldaláról világított rá arra a kérdésre, hogy az életkori szabályok merev alkalmazása nem szolgálja kellő hatékonysággal sem a bủnmegelőzést, sem a bűnüldözést. Álláspontja szerint tizenkét éves kortól a legsúlyosabb büncselekmények esetén már fennállhat a büntetőjogi felelősséget megalapozó belátási képesség, így célszerű lenne több életkori korhatárszektort kialakítani, és a büntetőjogi felelősséget a szektorok szerint növelni, párhuzamosan a büncselekményekért kiszabható szankciók fokozatos szigorításával. ${ }^{43}$

Blaskó Béla tankönyvében hasonló indokok alapján támogatja az új szabályozást. Kriminálpolitikailag helyesnek és megalapozottnak tartja a büntethetőség korhatárának szektorális leszállítását, azonban véleménye szerint a rendelkezés büntetőjogelméleti vonatkozásban több - egyelöre nyitott - kérdést is felvet. Így többek között kiemeli, hogy vajon a „belátással” kifejezést azonos értelemben használja-e a Btk. a „belátási képességgel”? Ha igen, akkor ezt az egyébként a polgári jogban már „foglalt" kategóriát a polgári joggal azonos, avagy eltérő értelemben használja? ${ }^{44}$

\section{8. Összegzés}

2013. július 1-jén hatályba lépett hazánk új Büntető törvénykönyve, amely eldöntötte a több mint tíz éve folyó vitát a büntethetőség korhatárának változtatásáról. Összességében azonban megállapítható, hogy a szabályozás nem került gyökeresen átalakításra, hiszen az új kódex csak igen szűk körben, csupán öt bűncselekmény esetében teszi megdönthetővé a tizennégy éves korhoz füződő törvényi vélelmet, ha a tizenkettedik életévét betöltött elkövető rendelkezik a bűncselekmény következményeinek felismeréséhez szükséges belátással. E „szükséges belátás” vizsgálata és értékelése még akár pozitív hatásokkal is járhat a gyermekek és fiatalkorúak büntetőjogi felelősségének megállapítása során.

41 GYURKó: i. m., 89.

42 BEnczúr Csaba: Tények és gondolatok a gyermekbünözésröl. Ügyészek Lapja 2006/4, 37.

43 VASKUTI András: Életkor és belátási képesség a magyar büntetőjogban - jogalkotási és jogalkalmazási kérdések. In Kriminológiai Közlemények 65., Budapest, Magyar Kriminológiai Társaság, 2008, 17-18.

44 BLAskó Béla: Magyar Büntetőjog Általános Rész. Budapest-Debrecen, Rejtjel Kiadó, 2013, 201. 
Tóth Mihály szerint: „Vitatható, de nem alkalmazhatatlan döntés született, ami feltehetően nem befolyásolja érdemben a gyermekbünözés helyzetét és perspektíváit, így talán nem is ront javulásuk esélyein."45

Meggyőződésem szerint az új Btk. rendelkezésének értelmezése során nem a szabályozás helyénvalóságát kellene elsősorban vizsgálni, hanem azt, hogy miként lehet eredményesen, illetve eredményesebben fellépni a gyermek- és fiatalkori bünözés ellen, mind a büntetőjog, mind pedig a büntetőjogon kívüli eszközökkel. Ennek érdekében, de lege ferenda javaslatom, hogy szükség lenne az új Btk. rendelkezésének pontosítására, esetleg valamennyi fiatalkorú bủnelkövetőkre vonatkozó büntethetőségi feltételek újragondolására. Nagy reményt látok a jelenlegi szabályozással bevezetett belátás, belátási képesség vizsgálatában, amelyet nemcsak a tizenkettedik életévét betöltött, de tizennégy év alatti elkövetők esetében, hanem valamennyi fiatalkorú bủnelkövető esetében alkalmazni kellene. Ezzel lehetőség nyílna a beszámítási képesség mellett a bűnelkövető fiatalok erkölcsi és értelmi fejlettségének vizsgálatára, amely értékelné a fejlődés fiatalkorra jellemző sajátos fázisát.

Egyetértve és továbbgondolva Vaskuti András véleményét, kedvező lenne a fiatalkorúak büntetőjogi felelősségre vonásánál az életkori sajátosságokat és belátási képesség fejlődését figyelembe vett életkori csoportok kialakítása, így a legfiatalabbak - a tizenkettő és tizennégy év közöttiek, az új Btk. Szabályozásához hasonlóan - csak a szándékos halálokozást magába foglaló bűncselekmények megvalósítása esetében válhatnának büncselekmény alanyává, és velük szemben csupán intézkedés, elsősorban a szabadságelvonással nem járó intézkedés lenne alkalmazható. Nagyobb bűncselekményi körben lehetne felelősségre vonni a tizennégy és tizenhat év közötti fiatalokat, amely kört leginkább a személy elleni erőszakos, illetve a vagyon elleni erőszakos bủncselekmények esetében lehetne megállapítani. Velük szemben is természetesen elsősorban intézkedés alkalmazása indokolt, azonban kirívó esetekben elzárással is büntethetők lehetnének. Végül a tizenhat és tizennyolc év közötti fiatalok felelőssége már valamennyi büncselekmény esetében fennállna, a jelenlegi fiatalkorúakra vonatkozó szabályok alkalmazásával.

\begin{abstract}
In Hungary from the 1990s in line with the international tendencies a number of studies were published in the literature urging the reform of the criminal law dealing with juvenile crime. Simultaneously one can establish that among others due to the increasing criminal rate the reasoning for the reduction of the lower age limit of punishability to the age of 12 has started. During the codification process a number of arguments were given for and against the alteration of the age limit of punishability. However setting the lower age limit of punishability below fourteen can be found in the criminal law regulations of Hungary and also of other European countries. This paper examines the antecedents, reasons and possible amendments of the regulation of the new Criminal Code on the age of punishability.
\end{abstract}

45 TóтH Mihály: Egy büntetőjogász gondolatai a „vox populi” oldalvizén. Élet és Irodalom, 2012/35, 5. 